\title{
Temporal and spatial trends for trace metals in streams and rivers across Sweden (1996-2009)
}

\author{
B. J. Huser, S. J. Köhler, A. Wilander, K. Johansson, and J. Fölster \\ Swedish University of Agricultural Sciences, Department of Aquatic Sciences and Assessment, P.O. Box 7050, \\ 75007 Uppsala, Sweden
}

Received: 3 January 2011 - Published in Biogeosciences Discuss.: 28 January 2011

Revised: 10 June 2011 - Accepted: 16 June 2011 - Published: 11 July 2011

\begin{abstract}
Long term data series (1996 through 2009) for trace metals were analyzed from a large number of streams and rivers across Sweden varying in tributary watershed size from 0.05 to $48193 \mathrm{~km}^{2}$. The final data set included 139 stream sites with data for arsenic (As), cobalt (Co), copper $(\mathrm{Cu})$, chromium $(\mathrm{Cr})$, nickel $(\mathrm{Ni})$, lead $(\mathrm{Pb})$, zinc $(\mathrm{Zn})$, and vanadium $(\mathrm{V})$. Between $7 \%$ and $46 \%$ of the sites analyzed showed significant trends according to the seasonal Kendall test. However, in contrast to previous studies and depositional patterns, a substantial portion of the trends were positive, especially for $\mathrm{V}(100 \%)$, As (95\%), and $\mathrm{Pb}(68 \%)$. Other metals ( $\mathrm{Zn}$ and $\mathrm{Cr}$ ) generally decreased, were mixed (Ni and $\mathrm{Zn}$ ), or had very few trends (Co) over the study period. Trends by region were also analyzed and some showed significant variation between the north and south of Sweden. Regional trends for both $\mathrm{Cu}$ and $\mathrm{Pb}$ were positive $(60 \%$ and $93 \%$, respectively) in the southern region but strongly negative (93\% and $75 \%$, respectively) in the northern region. Kendall's $\tau$ coefficients were used to determine dependence between metals and potential in-stream drivers including total organic carbon (TOC), iron (Fe), $\mathrm{pH}$, and sulphate $\left(\mathrm{SO}_{4}^{2-}\right)$. TOC and $\mathrm{Fe}$ correlated positively and strongly with $\mathrm{As}, \mathrm{V}, \mathrm{Pb}$, and $\mathrm{Co}$ while $\mathrm{pH}$ and $\mathrm{SO}_{4}^{2-}$ generally correlated weakly, or not at all with the metals studied.
\end{abstract}

\section{Introduction}

Because of the potential toxicity to biota, even at low concentrations, trace metals are of interest in surface waters. Temporal trends for metals in surface waters have emerged as an important topic in Europe in connection with the European Union Water Framework Directive (EUWFD, 2000),

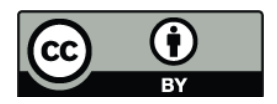

Correspondence to: B. J. Huser (brian.huser@slu.se) for determination of background levels, and in relation to how changes in climate, anthropogenic inputs, and land use may play in driving metal concentrations over time. However, long term trends of metal concentrations in streams and rivers are generally lacking, especially on broader spatial scales.

Trace metals are naturally present in atmospheric, terrestrial and aquatic environments and anthropogenic releases of metals occur due to human activities. Cycling of metals is complex because many factors influence metal behavior including biotic and abiotic chemical processes, hydrology, climate, land use and the properties of the metals themselves. A general regulator of mobility, $\mathrm{pH}$ affects the solubility of many metal ions. However, other factors can affect the mobility and transport of metals to and within surface water systems. Organic matter mineralization and chemical processes (e.g. changes in sulphate concentration and ionic strength) can alter metal solubility and mobility (Landre et al., 2009; Porcal et al., 2009). Metal ions can also be adsorbed to oxides or clays and precipitate; or they may occur in suspended forms as colloids and (or) particles that contain these compounds (Lofts and Tipping, 2000). Large scale changes, such as climate change (e.g. changes in extreme precipitation events, temperature, snow cover, etc.) can either directly or indirectly affect metal dynamics (Olivie-Lauquet et al., 2001; Adkinson et al., 2008; Porcal et al., 2009).

Natural organic matter (NOM) can affect the solubility of trace metals by forming strong bonds and complexes. The majority of NOM in aquatic systems is of terrestrial origin (McKnight and Aitken, 1998) and allochtonous NOM is mostly comprised of humic and fulvic compounds that can complex with metals (Leenheer et al., 1998). A number of studies show the importance of colloid associated transport of some trace metals (Sholkovitz, 1976; Elderfield et al., 1990; Martin et al., 1995; Wen et al., 1997; Warnken et al., 2009; Pokrovsky et al., 2010) and link elevated iron (Fe) and total organic carbon (TOC) concentrations to increased

Published by Copernicus Publications on behalf of the European Geosciences Union. 
transport of some trace metals (Wällstedt et al., 2010). Temporal changes in dissolved organic carbon (DOC) in surface waters have been increasing in many areas over the past three decades (Freeman et al., 2001; Worrall et al., 2004; Evans et al., 2005; Skjelkvale et al., 2005; Burns et al., 2006; Monteith et al., 2007) although the changes are not always monotone (Erlandsson et al., 2008). These changes in DOC are likely to affect trace metal concentrations and fluxes in surface waters.

The form of metal (e.g. dissolved, colloidal, or particulate) may also be an important factor when describing temporal variation of metal concentrations (e.g. copper $(\mathrm{Cu})$, lead $(\mathrm{Pb})$ and zinc (Zn)) in surface waters. Sherrell and Ross (1999) showed that dissolved trace metal concentrations were generally correlated to stream flow and, to a lesser extent, $\mathrm{pH}$ but in some cases in-stream process ( $\mathrm{pH}$ and solution particle partitioning) were not able to explain temporal variations due to low particulate to dissolved metal ratios. Colloidal and particulate size fractions of trace metals (e.g. Fe, $\mathrm{Cu}, \mathrm{Zn}$, and $\mathrm{Pb}$ ) have been shown to vary independently temporally (Ross and Sherrell, 1999) and metals such as vanadium (V) and arsenic (As) are generally associated with colloidal or particulate Fe fractions (Wällstedt et al., 2010). A recent study on the partitioning between filtered and particulate metals in a large number of the same Swedish running waters studied herein indicates that the median values of the form of some metals $(\mathrm{Cu}, \mathrm{Zn}$, cadmium $(\mathrm{Cd})$, chromium $(\mathrm{Cr})$, cobalt $(\mathrm{Co})$, nickel (Ni), As, V) in the particulate fraction were all close to or less than $25 \%$ of the total metal concentration (Köhler 2010). Higher fractions occurred for $\mathrm{Pb}(39 \%), \mathrm{Fe}(38 \%)$, and Manganese (34\%) and there were strong indications that particulate $\mathrm{Pb}$ was co-transported with particulate $\mathrm{Fe}$.

Atmospheric deposition of most metals has been decreasing in Europe (Azimi et al., 2005; Harmens et al., 2008) and, more specifically in Sweden (Rühling and Tyler, 2001, 2004) since the 1970s. Gradients of deposition exist across the country of Sweden, however, with a significant decreasing spatial trend towards the northern portion of the country most likely due to the prevalence of emissions from central Europe and from main population centers within Sweden mainly located in the lower third of the country (Rühling and Tyler, 1971).

Very few detailed studies exist for long term ( $>5$ years) metal trends in streams or rivers of varying scale and the ones that do exist primarily include monitoring sites affected by point sources. This study presents a first look at long term trends for trace metal concentrations in streams and rivers across Sweden from 1996 through 2009. The results are compared with other in-stream parameters that may affect the transport of metals in streams to determine if in-stream chemical interactions can be linked to any of the trends detected for metal concentrations, both for the country as a whole, and spatially by region.

\section{Materials and methods}

\subsection{General description}

The streams included in this study are situated throughout Sweden (Fig. 1) and the data time series ranged from 1996 through 2009. All data were gathered from the Department of Aquatic Sciences and Assessment at the Swedish University of Agricultural Sciences (http://www. slu.se/vatten-miljo). All metals were analyzed using ICPMS and the same analytical methods, all accredited by the Swedish Board for Accreditation and Conformity Assessment (SWEDAC), were used during the time period of the study (1996-2009). Details on methods, detection limits, quality control and other information can be found at the website referenced above. Data analyzed include total concentrations of trace metals arsenic $\mathrm{As}, \mathrm{Cu}, \mathrm{Co}, \mathrm{Cr}, \mathrm{Ni}, \mathrm{Pb}, \mathrm{Zn}$, and $\mathrm{V}$. Other parameters analyzed included $\mathrm{Fe}, \mathrm{pH}$, sulphate $\left(\mathrm{SO}_{4}^{2-}\right)$, and TOC. Only monitoring sites that were not directly influenced by point sources (e.g. wastewater treatment plants, mining facilities, industrial plants, etc.) were included in the analysis. This initial group of monitoring sites totaled 351 streams that were included in a study to estimate potential background loading of metals in Sweden (Herbert, 2009). From these sites, streams that had a minimum of 8 years of data (with sampling occurring monthly) were selected and included in the final group, resulting in a final data set including 139 streams (Fig. 1). Collection of metals data varied within these streams so the total number of streams included for analysis of each metal varied (Table 1). To further analyze data spatially, the country was divided into two regions based on the "limes norrlandicus" ecotone which divides Sweden into a southern nemoral and boreo-nemoral zone and a northern boreal and alpine zone. Climate also varies between the regions with the major difference, outside of ecosystem type, being the southern region is warmer than the north. Thus, the limes norrlandicus represents the approximate boundary separating areas where flow is low during winter with pronounced snowmelt in spring (the north) and flow is more or less continuous during the year with little to no accumulation of snow during winter (south). Regional areas, watershed size, and land use are summarized in Table 2.

\subsection{Data handling and statistics}

Outliers were considered in the analysis (on an individual stream basis) and data were excluded if the measurement was at least two times higher than any other measurement in the data set and the filtered versus unfiltered absorbance (at $420 \mathrm{~nm}$ ) for the sample did not indicate elevated particulates, meaning the sample was likely contaminated. Less than detection limit values were treated by dividing the detection limit by two. The number of values that were lower than the detection limit in the chemistry data set was low (between $0 \%$ and $2.3 \%$ ) for all parameters included in this study. 


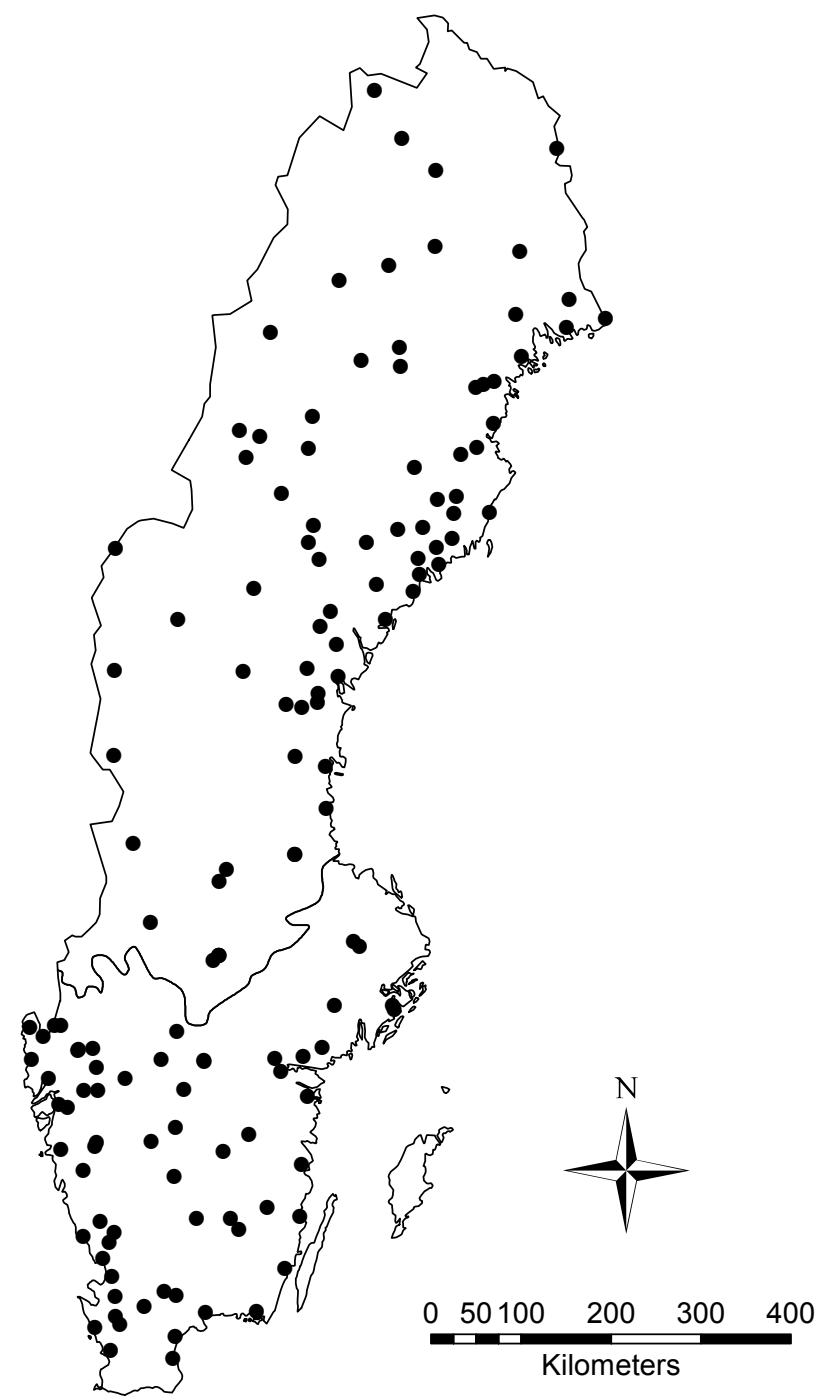

Fig. 1. All stream monitoring locations included in this study with the limes norrlandicus boundary separating the southern and northern regions.

Monthly data were available for all study sites; however, some stations had multiple data points available during some months, generally during the spring to autumn period. To reduce any bias from these periods, a monthly center analysis was conducted. Using this method, only data from one monitoring event, occurring closest to the middle of each month, was used in the analysis. Mean or median values for months with multiple sampling events were not used because this could influence the variance (Helsel and Hirsch, 1992).

Trends for time series data were determined by the Theil (Sen's) slope (Helsel and Hirsch, 1992). Statistical significance $(p \leq 0.05)$ of the trends was tested (both by site and by region) using the Seasonal Kendall test with Covariance Inversion (Loftis et al., 1991). These non-parametric methods were used because the data were not normally distributed and generally showed strong seasonal variation, introducing au-
Table 1. List of variables and associated medians with 10th and 90th percentiles (Pctls) by region.

\begin{tabular}{lllrlr}
\hline & \multicolumn{3}{c}{ North } & \multicolumn{2}{c}{ South } \\
\hline Variable & Sites & Median & 10,90 Pctls & Median & 10,90 Pctls \\
\hline $\mathrm{As}\left(\mu \mathrm{g} \mathrm{L}^{-1}\right)$ & 72 & 0.18 & $0.06,0.59$ & 0.41 & $0.25,0.70$ \\
$\mathrm{Co}\left(\mu \mathrm{g} \mathrm{L}^{-1}\right)$ & 70 & 0.057 & $0.021,0.23$ & 0.24 & $0.064,0.65$ \\
$\mathrm{Cr}\left(\mu \mathrm{g} \mathrm{L}^{-1}\right)$ & 73 & 0.18 & $0.08,0.49$ & 0.51 & $0.27,1.1$ \\
$\mathrm{Cu}\left(\mu \mathrm{g} \mathrm{L}^{-1}\right)$ & 90 & 0.51 & $0.20,1.0$ & 1.2 & $0.37,2.7$ \\
$\mathrm{Ni}\left(\mu \mathrm{g} \mathrm{L}^{-1}\right)$ & 70 & 0.36 & $0.14,0.95$ & 0.79 & $0.42,1.9$ \\
$\mathrm{~Pb}\left(\mu \mathrm{g} \mathrm{L}^{-1}\right)$ & 83 & 0.13 & $0.03,0.44$ & 0.44 & $0.15,1.1$ \\
$\mathrm{~V}\left(\mu \mathrm{g} \mathrm{L}^{-1}\right)$ & 71 & 0.14 & $0.04,0.48$ & 0.59 & $0.29,1.2$ \\
$\mathrm{Zn}\left(\mu \mathrm{g} \mathrm{L}^{-1}\right)$ & 88 & 1.8 & $0.60,5.0$ & 4.5 & $1.9,10$ \\
$\mathrm{Fe}\left(\mu \mathrm{g} \mathrm{L}^{-1}\right)$ & 106 & 320 & 66,1440 & 550 & 125,1700 \\
$\mathrm{pH}$ & 119 & 6.76 & $5.12,7.21$ & 6.93 & $4.80,7.84$ \\
$\mathrm{SO}{ }_{4}^{2-}\left(\mathrm{meq} \mathrm{L}^{-1}\right)$ & 121 & 0.046 & $0.025,0.10$ & 0.19 & $0.073,0.58$ \\
$\mathrm{TOC}\left(\mathrm{mg} \mathrm{L}^{-1}\right)$ & 119 & 6.5 & $2.4,14.8$ & 11.1 & $5.5,18.6$ \\
\hline
\end{tabular}

Table 2. Watershed area distribution (number of sites) and land use (\%) for study sites by region in Sweden.

\begin{tabular}{lcc}
\hline Category & North & South \\
\hline Agricultural & 1.2 & 15.5 \\
Forest & 53.4 & 55.3 \\
Open Field & 13.0 & 0.8 \\
Water & 22.1 & 21.7 \\
Urban & 0.3 & 1.2 \\
Other & 10.0 & 5.5 \\
\hline Total Area $\left(\mathrm{km}^{2}\right)$ & 287138 & 159855 \\
\hline Watershed Area Distribution & \\
\hline$\left(0-5 \mathrm{~km}^{2}\right)$ & 9 & 10 \\
$\left(5-25 \mathrm{~km}^{2}\right)$ & 14 & 11 \\
$\left(25-250 \mathrm{~km}^{2}\right)$ & 24 & 19 \\
$\left(>250 \mathrm{~km}^{2}\right)$ & 28 & 24 \\
\hline Total Sites & 75 & 64 \\
\hline
\end{tabular}

tocorrelation. By using the seasonal Kendall test, within season variability is taken into account so that only inter-annual variations within the data are assessed. These types of tests are also robust for extreme values and outliers. Individual Theil slopes were analyzed between regions for statistically significant differences using the Wilcoxon test $(p \leq 0.01)$.

Kendall's $\tau$ coefficient was used to determine relationships between general chemical stream parameters (TOC, $\mathrm{pH}, \mathrm{SO}_{4}^{2-}$, and $\mathrm{Fe}$ ) and trace metal concentrations. Kendall's $\tau$ is a non-parametric rank test that determines whether the analyzed parameters move in the same direction (concordant) or move in opposite directions (discordant). The coefficient score ranges from -1 to 1 with values of 1 or -1 meaning that all paired values are concordant or discordant, respectively. Statistical significance was determined at a level of $p \leq 0.001$. 
Table 3. Number of sites with statistically significant $(p<0.05)$ negative or positive Theil slope trends or no significant trend detected.

\begin{tabular}{lcccccc}
\hline & \multicolumn{3}{c}{ North } & \multicolumn{3}{c}{ South } \\
\hline Variable & Negative & Positive & No Trend & Negative & Positive & No Trend \\
\hline $\mathrm{As}$ & 1 & 9 & 27 & 0 & 11 & 24 \\
$\mathrm{Co}$ & 0 & 3 & 34 & 1 & 1 & 31 \\
$\mathrm{Cr}$ & 4 & 3 & 28 & 6 & 1 & 31 \\
$\mathrm{Cu}$ & 13 & 1 & 32 & 6 & 9 & 29 \\
$\mathrm{Ni}$ & 6 & 5 & 23 & 5 & 3 & 28 \\
$\mathrm{~Pb}$ & 6 & 2 & 32 & 1 & 13 & 29 \\
$\mathrm{~V}$ & 0 & 15 & 22 & 0 & 18 & 16 \\
$\mathrm{Zn}$ & 7 & 2 & 35 & 5 & 4 & 35 \\
$\mathrm{Fe}$ & 1 & 19 & 35 & 1 & 23 & 27 \\
$\mathrm{pH}$ & 1 & 12 & 54 & 0 & 13 & 39 \\
$\mathrm{SO}_{4}^{2-}$ & 40 & 1 & 27 & 44 & 0 & 9 \\
$\mathrm{TOC}$ & 1 & 14 & 52 & 0 & 22 & 30 \\
\hline
\end{tabular}

\section{Results}

Median values and 10th and 90th percentiles for study parameters are shown in Table 1 and values were lower for all parameters when comparing northern to southern Sweden. Trace metal and potential in-stream chemical driver concentrations showed either positive, negative, or a mixture of trends across the country (Table 3). Examples of monthly data from 1996-2009 for some significantly trending sites are shown for $\mathrm{Pb}, \mathrm{Cu}$, and TOC (Fig. 2a, b, c). While temporal trends showed patterns across the country as a whole, examination of trends spatially (by region) revealed both similar and diverging patterns, depending on the trace metal.

\subsection{Positive trending trace metals}

Both $\mathrm{V}$ and As had the most positive trends (all significantly trending sites were positive except for one As site) of the trace metals analyzed (Table 3, Fig. 3) and mean trends for each region followed this pattern as well (Table 4). Within region trends were significant for each metal within the northern region ( $p=0.002$ and 0.004 , respectively) but not in the southern region. One of the sites for $\mathrm{V}$ in the southern region (Nossan Sal) heavily influenced the trend analysis with a median value near the 90th percentile. However, this site did not have data for the final two years of the study period, essentially elevating the regional trend except in the final two years (2008-2009). If this site was removed, the regional analysis was significant $(p=0.02)$. Two sites with low As median concentrations $\left(0.28\right.$ and $\left.0.29 \mu \mathrm{g} \mathrm{L}^{-1}\right)$ near the 10 th percentile, also in the southern region, did not have monitoring data until the beginning of 1998 and 2000, basically lowering the overall regional trend in later years. Without these two sites, the regional trend for As was also positive $(p=0.03)$. Comparison of trends between regions using the Wilcoxon test were not significant for trend slopes in percentage per year $\left(\% \mathrm{yr}^{-1}\right)$ but the test for slope in concentration
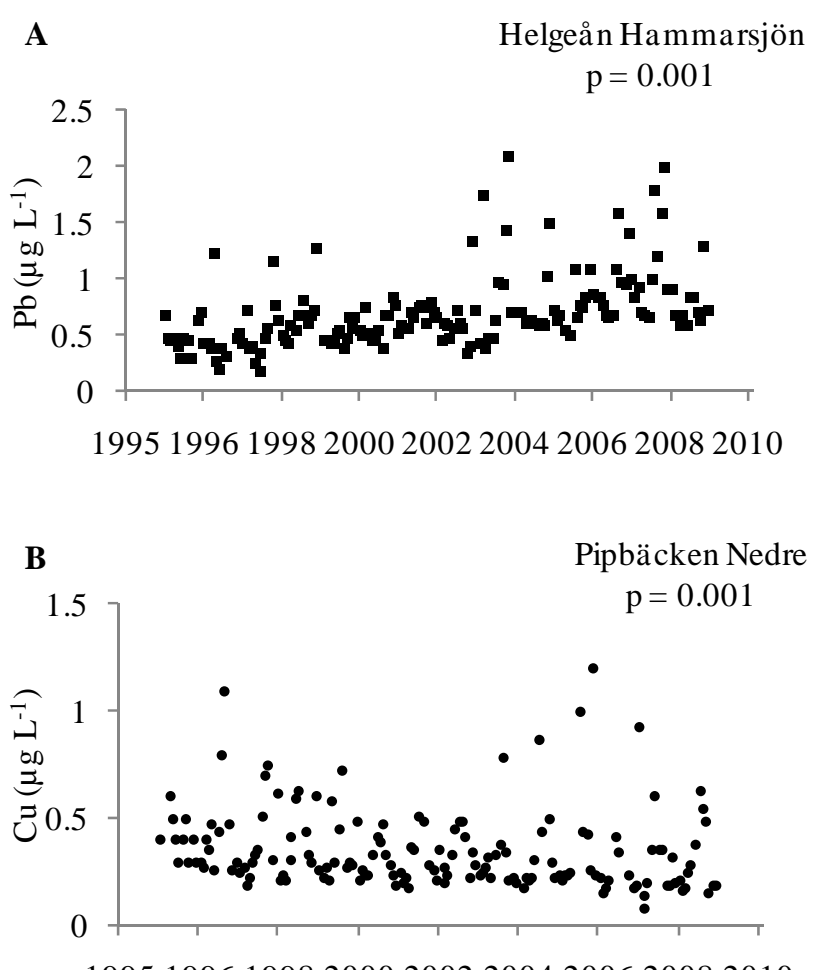

199519961998200020022004200620082010

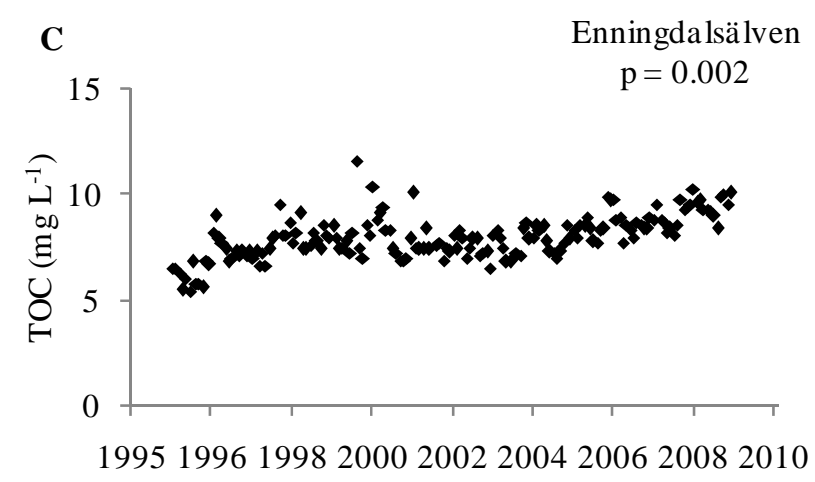

Fig. 2. Selected monitoring locations showing long-term raw-data series for $\mathrm{Pb}, \mathrm{Cu}$, and TOC. $\mathrm{P}$ values indicating trend significance are shown under the name of each site.

per year (conc. $\mathrm{yr}^{-1}$ ) for $\mathrm{V}$ did show a significant difference $(P=0.0001)$. However, this difference was due to the large difference in concentration between the sites in the northern and southern regions, not a difference in trend direction.

\subsection{Mixed positive and negative trending metals}

While Theil slope trends for $\mathrm{Pb}$ were predominantly positive on a country-wide basis, there was a diverging trend between regions (Table 3, Fig. 3). Mean trend change in $\% \mathrm{yr}^{-1}$ was -2.4 in the northern portion of the country while the southern portion showed a mean positive trend of $4.5 \% \mathrm{yr}^{-1}$. Mean trends in concentration showed the same directional 
B. J. Huser et al.: Temporal and spatial trends for trace metals in streams and rivers

$\mathrm{Ni}$

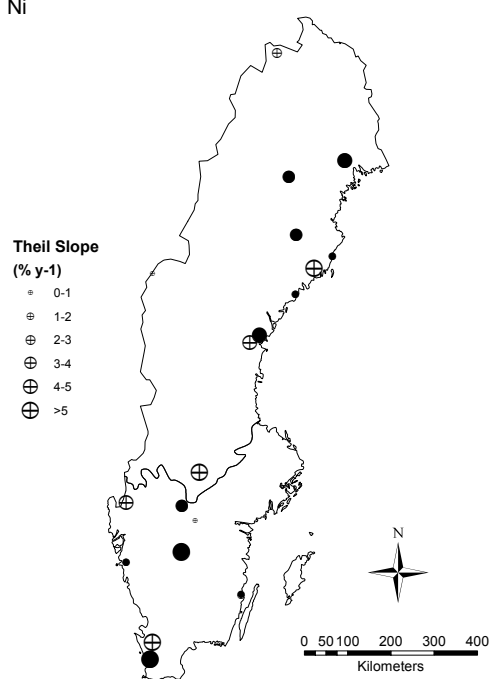

$\mathrm{Pb}$

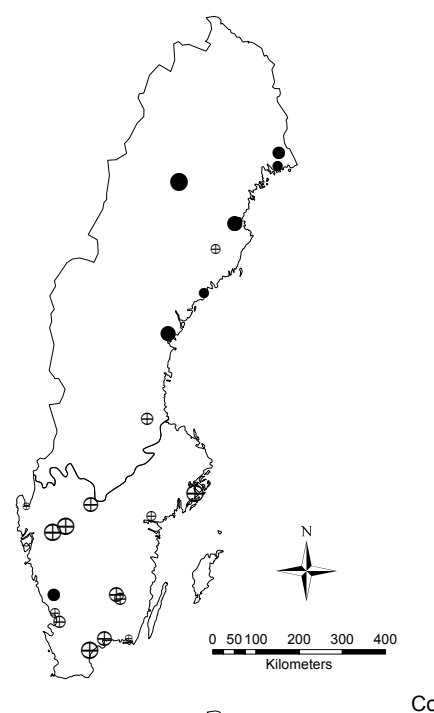

$\mathrm{Cr}$

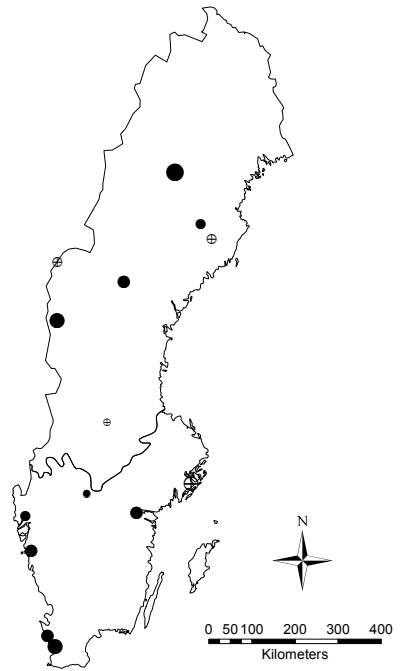

Co

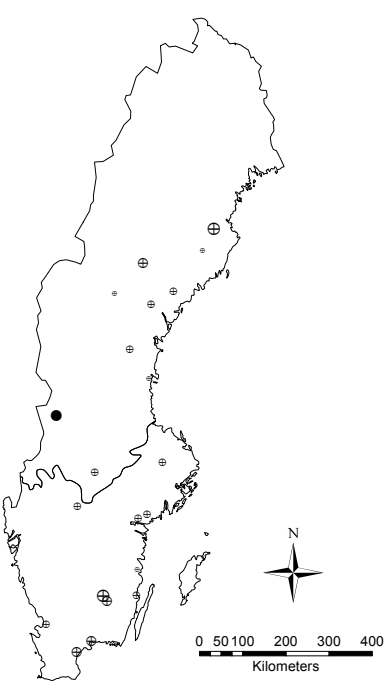

$\mathrm{Cu}$

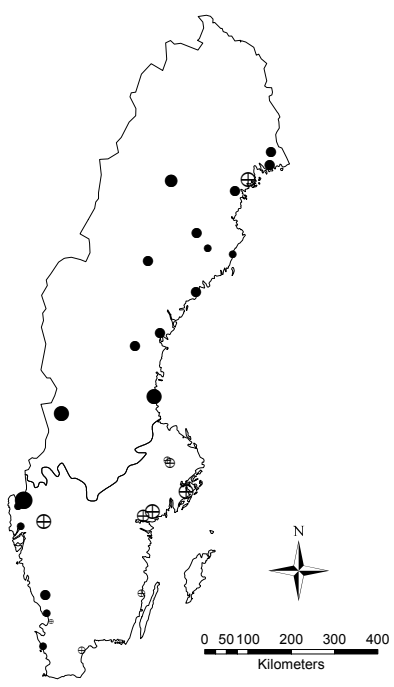

$\checkmark$

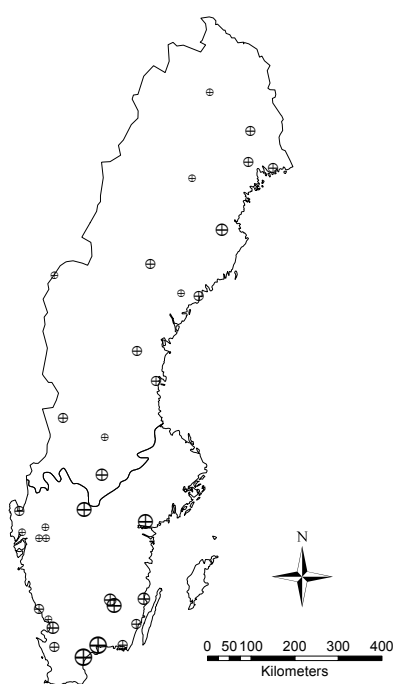

$\mathrm{Zn}$

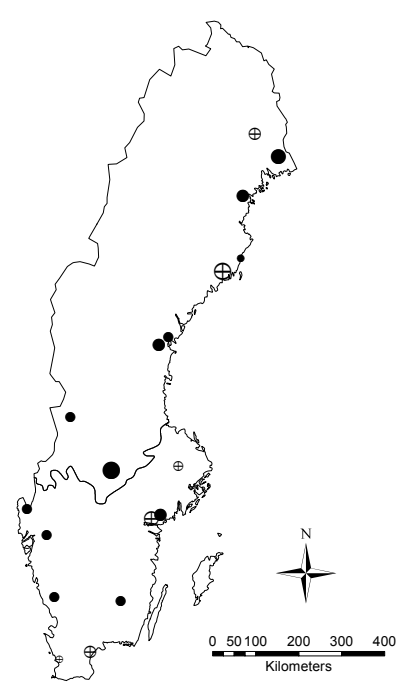

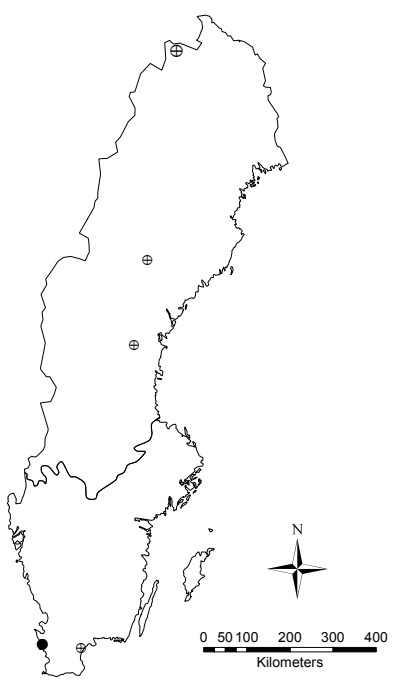

Fig. 3. Metal trends indicated by shaded (negative) or crossed, open (positive) circles. The size of the circle represents the magnitude of the trend slope in $\% \mathrm{yr}^{-1}$. 
Table 4. Mean of statistically significant $(p \leq 0.05)$ Theil slope values and standard deviations (in parentheses) by concentration and percentage change per year for each variable.

\begin{tabular}{lrrrr}
\hline Variable & \multicolumn{2}{c}{ North } & \multicolumn{2}{c}{ South } \\
\hline & Unit yr $^{-1}$ & $\% \mathrm{yr}^{-1}$ & $\mathrm{Unit} \mathrm{yr}^{-1}$ & $\% \mathrm{yr}^{-1}$ \\
\hline $\mathrm{As}\left(\mu \mathrm{g} \mathrm{L}^{-1}\right)$ & $0.010( \pm 0.018)$ & $1.4( \pm 0.96)$ & $0.007( \pm 0.003)$ & $1.7( \pm 0.77)$ \\
$\mathrm{Co}\left(\mu \mathrm{g} \mathrm{L}^{-1}\right)$ & $0.004( \pm 0.002)$ & $2.8( \pm 0.34)$ & $0.001( \pm 0.013)$ & $0.16( \pm 4.0)$ \\
$\mathrm{Cr}\left(\mu \mathrm{g} \mathrm{L}^{-1}\right)$ & $0.004( \pm 0.011)$ & $-1.5( \pm 3.5)$ & $-0.009( \pm 0.032)$ & $-2.1( \pm 3.1)$ \\
$\mathrm{Cu}\left(\mu \mathrm{g} \mathrm{L}^{-1}\right)$ & $-0.013( \pm 0.013)$ & $-2.3( \pm 2.1)$ & $0.026( \pm 0.062)$ & $0.59( \pm 3.3)$ \\
$\mathrm{Ni}\left(\mu \mathrm{g} \mathrm{L}^{-1}\right)$ & $0.003( \pm 0.016)$ & $0.42( \pm 4.8)$ & $-0.018( \pm 0.061)$ & $-1.6( \pm 5.0)$ \\
$\mathrm{Pb}\left(\mu \mathrm{g} \mathrm{L}^{-1}\right)$ & $-0.0004( \pm 0.008)$ & $-2.4( \pm 3.5)$ & $0.023( \pm 0.024)$ & $4.5( \pm 4.2)$ \\
$\mathrm{V}\left(\mu \mathrm{g} \mathrm{L}^{-1}\right)$ & $0.006( \pm 0.006)$ & $2.2( \pm 0.65)$ & $0.020( \pm 0.012)$ & $3.1( \pm 1.3)$ \\
$\mathrm{Zn}\left(\mu \mathrm{g} \mathrm{L}^{-1}\right)$ & $-0.054( \pm 0.168)$ & $-0.50( \pm 4.4)$ & $-0.027( \pm 0.172)$ & $-0.099( \pm 3.1)$ \\
$\mathrm{Fe}\left(\mu \mathrm{g} \mathrm{L}^{-1}\right)$ & $-2.73( \pm 118.02)$ & $1.6( \pm 8.7)$ & $12.9( \pm 46.00)$ & $2.4( \pm 4.7)$ \\
$\mathrm{pH}$ & $0.013( \pm 0.011)$ & $0.21( \pm 0.20)$ & $0.015( \pm 0.007)$ & $0.25( \pm 0.14)$ \\
$\mathrm{SO}{ }_{4}^{2-}\left(\mathrm{meq} \mathrm{L}^{-1}\right)$ & $-0.001( \pm 0.002)$ & $-2.7( \pm 2.0)$ & $-0.008( \pm 0.005)$ & $-4.3( \pm 1.4)$ \\
$\mathrm{TOC}\left(\mathrm{mg} \mathrm{L}^{-1}\right)$ & $0.223( \pm 0.230)$ & $3.0( \pm 2.2)$ & $0.249( \pm 0.130)$ & $2.1( \pm 0.73)$ \\
\hline
\end{tabular}

trends (Table 4). Regional trends were not significant but there was a significant difference between regions both by concentration and percentage change per year $(p=0.005$ and $p=0.003$, respectively).

Although temporal trends across the country were predominantly negative, $\mathrm{Cu}$ is another metal that had divergent regional trends. Mean percentage trends were negative in the north $\left(-2.3 \% \mathrm{yr}^{-1}\right)$ and positive in south $\left(0.59 \% \mathrm{yr}^{-1}\right)$ of Sweden (Table 4). Neither region showed an overall significant trend but comparisons between regions for trends in concentration and percentage change were both significant ( $p=0.01$ and $p=0.0017$, respectively).

Mean trend slopes for both $\mathrm{Zn}$ and $\mathrm{Cr}$ were negative in the north $\left(-0.5 \% \mathrm{yr}^{-1}\right.$ and $-1.5 \% \mathrm{yr}^{-1}$, respectively) and the south ( $-0.099 \% \mathrm{yr}^{-1}$ and $-2.1 \% \mathrm{yr}^{-1}$, respectively) of Sweden (Table 4). Regional seasonal Kendall tests for $\mathrm{Cr}$ showed statistically significant negative trends in both the north $(p=0.05)$ and south $(p=0.04)$ and the comparison between regions showed no statistical difference in trends for concentration or percentage change. However, regional tests for $\mathrm{Zn}$ initially showed statistically significant positive trends in both the north and south even though the average trend slopes were negative for each region. The reason for this is that single sites in both the northern and southern regions substantially affected the regional trend analyses. Sävjaån Kuggebro, one of the positive trending sites in the south, had a median $\left(8.0 \mu \mathrm{g} \mathrm{L}^{-1}\right)$ near at the 90th percentile and generally had values substantially higher than other sites in the southern region. Annual median values for Ume älv Stornorrfors (a positive tending site in the north) were near the 10 percentile from 1996 to 2000 (1.4 to $2.8 \mu \mathrm{g} \mathrm{L}^{-1}$ ) but increased to greater than the 90th percentile by 2009 $\left(7.8 \mu \mathrm{g} \mathrm{L}^{-1}\right)$. Thus, both of these sites positively skewed the regional analyses even though the majority of statistically significant trending sites were negative. Without these sites, regional trends for both northern and southern Sweden were negative and statistically significant $(p=0.0006$ and $p=0.004$, respectively). No significant differences were found when comparing $\mathrm{Zn}$ trends between regions, both with and without the two sites listed above included in the analysis.

$\mathrm{Ni}$ showed opposite mean regional trends compared to $\mathrm{Cu}$ and $\mathrm{Pb}$, with a positive mean percentage trend $\left(0.42 \% \mathrm{yr}^{-1}\right)$ in the north and a negative mean percentage trend $\left(-1.6 \% \mathrm{yr}^{-1}\right)$ in the south (Table 4$)$. However, there were more statistically significant negative (6) than positive (5) sites in northern Sweden. The regional test also showed a statistically significant negative trend in the north $(p=0.02)$. No significant regional trend was detected in the south. Comparison between regions for concentration and percentage trends showed no statistical difference for either trend slope measure.

\subsection{Low number trending sites}

Co showed overall positive trends but the total number of statistically significant sites was low, with only 3 sites in the northern area and 2 sites in the southern area. Because of the low number of significant sites, regional tests although positive, are not included.

\subsection{General water chemistry trends}

Trends for the potential water chemistry drivers were either predominantly positive (TOC, $\mathrm{Fe}, \mathrm{pH})$ or negative $\left(\mathrm{SO}_{4}^{2-}\right)$ showing similar trends in both regions of the country (Table 3). TOC and $\mathrm{pH}$ mean increases were $3.0 \% \mathrm{yr}^{-1}$ and 
$0.21 \% \mathrm{yr}^{-1}$ in the north and $2.1 \% \mathrm{yr}^{-1}$ and $0.25 \% \mathrm{yr}^{-1}$ in the south, respectively. Mean percentage trends for Fe were both positive at $1.6 \% \mathrm{yr}^{-1}$ in the north and $2.4 \% \mathrm{yr}^{-1}$ in the south. $\mathrm{SO}_{4}^{2-}$ trends were negative in northern and southern areas $\left(-2.7 \% \mathrm{yr}^{-1}\right.$ and $-4.3 \% \mathrm{yr}^{-1}$, respectively) and were significant on a regional basis. Both $\mathrm{pH}$ and $\mathrm{Fe}$ showed no significant difference between regions for either concentration or percentage trends. TOC trends showed no significant difference between regions while $\mathrm{SO}_{4}^{2-}$ trends between regions resulted in significant differences for both concentration and percentage trends $(P<0.0001$ for both).

\subsection{Correlations between potential drivers and trace metals concentrations}

To assess relationships between in-stream chemical parameters and trace metals analyzed in this study, the nonparametric Kendall's $\tau$ coefficient test was used (Table 5). Most coefficients were low (i.e. $<0.4$ ) however some interdependence was shown. $\mathrm{Pb}$, As, and $\mathrm{V}$ were concordantly related with TOC both in the northern and southern regions of Sweden. Surprisingly, $\mathrm{Cu}$ was not well correlated with TOC and the relationship was either not significant (south) or showed a weak relationship (north). Cr showed a somewhat weak relationship with TOC in the north and a very weak relationship in the south of Sweden. $\mathrm{Pb}, \mathrm{Zn}, \mathrm{As}, \mathrm{V}$ and $\mathrm{Cr}$ showed strong relationships with $\mathrm{Fe}$ concentration with both $\mathrm{Pb}$ and $\mathrm{V}$ showing this trend in northern and southern Sweden. $\mathrm{Pb}$ and $\mathrm{Cr}$ correlated (discordantly) well with $\mathrm{pH}$ in northern Sweden and this trend was similar, although weaker, in southern Sweden. Zn also showed weak, discordant relationships with $\mathrm{pH}$ in both regions. Most metals did not show a strong relationship with $\mathrm{SO}_{4}^{2-}$.

\section{Discussion}

This study presents a first look at long term trends in trace metal concentrations in streams across the country of Sweden. The results show a clear, spatial gradient for all stream parameters with higher levels being detected in the south of Sweden. Temporal trends in trace metal stream concentrations showed both consistent and variable trends over the study period (1996-2009).

Although data on long term tends for trace metals in streams are very limited, it would be expected that metals with a high affinity for organic matter or suspended organometallic colloids (e.g. V, As, $\mathrm{Cu}, \mathrm{Pb}, \mathrm{Cr}$ ) would increase along with increasing trends in TOC or TOC and Fe, assuming no other substantial changes in chemical composition within the water body or other outside influences. This was the case with both $\mathrm{V}$ and As which showed a high percentage of positive trends $(100 \%$ and $95 \%$ of significant trends, respectively) over the study period (1996-2009). Wällstedt et al. (2010) also detected increasing concentration trends for
$\mathrm{V}$ and As in a number of streams in southern Sweden and posited that these trends were due, in large extent, to increasing concentrations of colloidal Fe which is stabilized by increasing DOC. Our results support this reasoning with strong, concordant relationships generally found between TOC and Fe, and $\mathrm{V}$ and As (Table 5). In addition, As (as arsenate) is less mobile at lower $\mathrm{pH}$ values, being bound to iron hydroxide, and becomes more mobile as $\mathrm{pH}$ increases (McBride, 1994). However, As was not well correlated with $\mathrm{pH}$ in either the north or south of Sweden, probably due to $\mathrm{pH}$ trends falling generally within the near neutral range. The resulting strong increasing trends in both $\mathrm{V}$ and As are especially surprising given that deposition of $\mathrm{V}$ and As decreased from 1975 through 2000 by factors of 5.5 and 5.3, respectively (Rühling and Tyler, 2004) which should translate into an approximate average $20 \% \mathrm{yr}^{-1}$ decreasing slope.

In contrast to $\mathrm{V}$ and $\mathrm{As}, \mathrm{Cr}$ showed predominantly negative trends across the country (71\% of significant sites), but with a higher percentage of negative trending sites in the south compared to the north $(86 \%$ and $57 \%$, respectively). Kendall's $\tau$ coefficients were generally weak or not significant for most in-stream water chemistry variables. Fe showed a strong, concordant relationship in the northern region of Sweden, which could partially explain a higher percentage of positive trending sites in this area compared to the southern region.

Similarly, a majority of the $\mathrm{Cu}$ trends were negative for the country as a whole $(66 \%)$ and 13 of 14 sites trended negatively in the north $(97 \%)$. However, trends were predominantly positive in southern Sweden $(60 \%)$. Relationships between TOC and $\mathrm{Cu}$ were inconclusive, with no significant relationship in the northern region and a weak, concordant relationship in the south. This is somewhat surprising given that $\mathrm{Cu}$ binds with organic matter strongly (Sauve et al., 1997). In fact, $\mathrm{Cu}$ was weakly correlated with all in-stream chemical parameters included in this study, showing the strongest relationship with $\mathrm{pH}$ in the southern region $(0.39)$ and $\mathrm{SO}_{4}^{2-}$ in both regions (north $=0.36$ and south $=0.33$ ). Other studies have shown difficulty in determining relative factors driving $\mathrm{Cu}$ concentrations in surface waters as well, especially with respect to DOM. Landre et al. (2009) showed that $\mathrm{Cu}$ was not significantly related to DOC even though significant relationships were found for other metals that bind strongly with DOC. Grybos et al. (2007) and Schut et al. (1986) found no significant relationships between $\mathrm{Cu}$ and DOC or $\mathrm{pH}$ in different wetland systems.

It is likely that other factors are driving the patterns for trends in $\mathrm{Cu}$ by region. $\mathrm{Cu}$ did correlate moderately with $\mathrm{pH}$ in the southern region, tending to increase as $\mathrm{pH}$ increased. Mobility of $\mathrm{Cu}$ can increase as $\mathrm{pH}$ increases in alkaline soils, where $\mathrm{Cu}$ can form hydroxyl or carbonate complexes. Although most soils in Sweden are not alkaline in nature, the northeast area of the southern region is dominated by alkaline soils. The majority of positive trends for $\mathrm{Cu}$ in the southern region were found in this area with alkaline soils. Thus, it 
Table 5. Kendall's $\tau$ coefficients for relationships between in-stream chemical parameters and trace metals, by region. Non-significant $(p \leq 0.001)$ relationships are denoted by N.S. and strong relationships $(>0.4)$ are bold.

\begin{tabular}{c|cc|cc|cc|cc}
\hline \multirow{2}{*}{ Metal } & \multicolumn{2}{|c|}{$\mathrm{pH}$} & \multicolumn{2}{c|}{$\mathrm{SO}_{4}^{2-}$} & \multicolumn{2}{c|}{ TOC } & \multicolumn{2}{c}{ Fe } \\
\hline & North & South & North & South & North & South & North & South \\
\hline $\mathrm{As}$ & -0.23 & 0.33 & N.S. & 0.24 & $\mathbf{0 . 5 2}$ & $\mathbf{0 . 4 2}$ & $\mathbf{0 . 6 1}$ & 0.24 \\
$\mathrm{Co}$ & -0.34 & -0.26 & $-\mathbf{0 . 4 8}$ & -0.21 & $\mathbf{0 . 5 6}$ & 0.26 & $\mathbf{0 . 7 5}$ & 0.39 \\
$\mathrm{Cr}$ & $-\mathbf{0 . 4 3}$ & -0.12 & -0.14 & N.S. & 0.38 & 0.09 & $\mathbf{0 . 4 1}$ & 0.38 \\
$\mathrm{Cu}$ & 0.13 & 0.39 & 0.36 & 0.33 & N.S. & 0.15 & 0.06 & -0.06 \\
$\mathrm{Ni}$ & -0.12 & 0.38 & 0.15 & $\mathbf{0 . 4 8}$ & 0.16 & N.S. & -0.06 & N.S. \\
$\mathrm{Pb}$ & $-\mathbf{0 . 5 3}$ & -0.05 & 0.12 & 0.13 & $\mathbf{0 . 5 7}$ & $\mathbf{0 . 5 3}$ & $\mathbf{0 . 5 6}$ & $\mathbf{0 . 6 5}$ \\
$\mathrm{V}$ & -0.17 & 0.06 & N.S. & 0.13 & $\mathbf{0 . 4 9}$ & $\mathbf{0 . 4 4}$ & $\mathbf{0 . 4 2}$ & $\mathbf{0 . 5 2}$ \\
$\mathrm{Zn}$ & -0.40 & -0.28 & 0.16 & -0.09 & 0.21 & 0.31 & 0.11 & $\mathbf{0 . 4 1}$ \\
\hline
\end{tabular}

appears that $\mathrm{pH}$ may drive increasing trends in this specific area of Sweden. However, it appears that other factors, outside those included in this study, influence most of the sites with significant trends.

$\mathrm{Pb}$ followed a similar pattern to $\mathrm{Cu}$ with mostly negative trends in the north (75\%) and nearly all positive trends in the south $(93 \%)$. This is in contrast to the depositional pattern of $\mathrm{Pb}$, which declined by a factor of 11.3 between 1975 and 2000 (Rühling and Tyler, 2004). While $\mathrm{Pb}$ correlated well with TOC and Fe (Table 5) and has been shown by others to correlate well with colloidal Fe (Pokrovsky and Schott, 2002), $\mathrm{Pb}$ is also linked to urban land use (Fitzpatrick et al., 2007) and the southern region of Sweden contains most of the population centers. In addition, historical depositional patterns have been show to be as much as 8 times higher in the south compared to the north of Sweden (Rühling and Tyler, 1971). Thus, it seems likely that the difference in trends between regions may be partially explained by the difference in historical catchment deposition, storage and the related response time to changes in atmospheric deposition which have been shown for metals that bind strongly with organic matter (Tipping et al., 2010).

Other metals, such as $\mathrm{Ni}$ and $\mathrm{Zn}$, do not bind as strongly to solid surfaces in soils and could be expected to have a faster transit time from watershed soils to rivers (Tipping et al., 2010), provided deposition is the main source. Thus, these metals may respond more directly with depositional patterns, especially if the sites were generally undisturbed by point sources or changes in land use. Both $\mathrm{Zn}$ and $\mathrm{Ni}$ showed predominantly decreasing trends overall $(67 \%$ and $71 \%$, respectively). Neither metal showed much in the way of correlation with in-stream chemical parameters except for $\mathrm{SO}_{4}^{2-}(\mathrm{Ni})$ and $\mathrm{Fe}(\mathrm{Zn})$, both in southern Sweden. Changes in concentration are likely driven by other factors (e.g. deposition, watershed characteristics, and (or) land use) rather than changes in TOC or other general in-stream chemical parameters included in this study.

Co showed few, but overall positive trends in Sweden. Kendall's $\tau$ correlation analysis showed only weak effects on Co concentrations by in-stream parameters in southern Sweden but in the northern region, $\mathrm{SO}_{4}^{2-}$ and TOC showed fairly strong correlations (Kendall's $\tau=-0.48$ and 0.56 , respectively) while $\mathrm{Fe}$ showed a very strong correlation (0.75). Co has been shown to be linked to Fe-oxyhydroxides (Grybos et al., 2007), especially in wetland systems undergoing redox reactions. The few sites showing positive trends in this study are near wetlands that could be changing over time (e.g. increased degradation of OM resulting in lower redox conditions) due to climate or other changes affecting the area. However, there are not enough data to confirm this.

The results for the trace metals presented herein, at least in part, contradict strong, negative depositional patterns. The most recent study of metal deposition trends over Sweden showed that all 60 elements studied had decreased from 1975 to 2000 (Rühling and Tyler, 2004), including the eight trace metals analyzed in this study. Although the time period for our study ranges from 1996 through 2009, the results from the deposition study show clear, statistically significantly declining trends for the metals included in our study, ranging from a factor of $1.7(\mathrm{Cu})$ to $11.3(\mathrm{~Pb})$ between 1975 and 2000. Stores of trace metals in watershed soils can be significant and are likely higher in the southern region of Sweden due to local activity and long range transport and deposition (Rühling and Tyler, 1971). As others have shown, catchment soils can accumulate trace metals such as $\mathrm{Pb}$ (Lindberg and Turner, 1988), and may respond on the time scale of decades, or even centuries, to changes in deposition (Lawlor and Tipping, 2003). Transit times for different metals will vary based on their affinity for watershed soils (Tipping et al., 2010). Thus, metals with lower affinity for soil particles and/or organic matter (e.g. Ni and $\mathrm{Zn}$ ) may respond more quickly to changes in depositional patterns compared to those metals with higher affinity for NOM or organo-metallic colloids (e.g. V, As, $\mathrm{Pb}, \mathrm{Cu}$, and $\mathrm{Cr}$ ).

Of the available long term studies of metal concentrations in rivers, decreasing trends are generally seen for some of the trace metals included in this study. $\mathrm{Cu}, \mathrm{Ni}, \mathrm{Pb}$, and $\mathrm{Zn}$ steadily increased in four rivers in the Netherlands during 
the 20th century until the latter half of the 1970s when the trends started to reverse (Salomons and Eysink, 1979; Salomons and Forstner, 1984). Foster and Charlesworth (1996) showed declining concentrations between 1974 and 1993 for $\mathrm{Cu}, \mathrm{Ni}, \mathrm{Pb}$, and $\mathrm{Zn}$ for two rivers in the United Kingdom. However, these studies included sites heavily affected by point sources including direct inflows of metals, mainly from wastewater treatment facilities. Given the implementation of point source reduction practices across the industrialized world in the mid to late 1970s, it is not surprising there would be declines in the concentration of most trace metals in such streams.

Lettenmaier et al. (1991) analyzed times series data (1978 to 1987) in rivers in the US for a suite of traces metals finding significant trends ranging from $1 \%(\mathrm{Ag})$ to $25 \%$ (As) of the study sites $(N=312$ to 383$)$, most of which trended negatively (including $\mathrm{Cu}, \mathrm{Ni}, \mathrm{Zn}, \mathrm{As}, \mathrm{Cr}, \mathrm{Fe}$ and $\mathrm{Pb}$ ). Lettenmaier et al. (1991) also tested for association between trace metals and varying land use factors and flow, however, the results were largely inconclusive. Although some of the results from the US study tend to agree with this study with mutual declines $(\mathrm{Cu}, \mathrm{Ni}, \mathrm{Zn}$, and $\mathrm{Cr}$ ), some differed with overall increases found in this study ( $\mathrm{As}, \mathrm{Fe}$, and $\mathrm{Pb}$ ). This is not unexpected however, given the different time frame, geographical location, climate and land use patterns, and the fact that some of the streams in the Lettenmaier et al. (1991) study were likely affected by changes in point source inputs.

Although strong correlations were found between some trace metals and TOC and $\mathrm{Fe}$, we can not ignore the likelihood that other factors not analyzed in this study may contribute to the trends detected in this analysis. Climatic changes (including effects on ground water and soil temperature) may affect both the mobility and transport of metals. Higher temperatures can lead to elevated degradation rates of OM, potentially leading to increases in DOC and trace metals in soil pool water (Dalva and Moore, 1991). An increase in extreme precipitation events can also affect transport. Droughts allow for increased oxidation of NOM and formation of DOC (Worrall and Burt, 2004) while extreme precipitation events alter hydrologic pathways from watersheds to streams (Hongve et al., 2004), potentially increasing the leaching of organic compounds from surficial soils. Decreased ionic strength, due mainly to decreased loading of $\mathrm{SO}_{4}^{2-}$ over Sweden, is also likely to play a role in changing DOC and associated trace metal concentrations in streams and rivers, by controlling the precipitation and disassociation of organic acids (Thurman, 1985).

Changes in climate have occurred over the study period in Sweden, both across the country and by region. The UN Intergovernmental Panel on Climate Change (IPCC), summarized in a Swedish governmental report 2007:60 (SOU, 2007), shows that temperatures have been increasing in recent years across Sweden. Precipitation has also been increasing in all seasons except autumn. The report predicts that Sweden, as a whole, will become warmer and wetter due to the effects of climate change. Thus, changes in climate can, and will continue to exert influence on trace metal mobility and transport, both directly and indirectly.

Some care should be taken when interpreting long term trends for heavy metals in surface waters. Trends for trace metals determined in this study are highly dependent on the time frame used and the results should be used with caution when attempting to infer trends during other periods. This study also reveals that caution must be taken when analyzing long term trends with large data sets. Single sites may have an unusually large effect on regional trend analyses for trace metals (as well as other parameters). Although cumbersome, site by site inspection of data series (completed in this study) should be conducted to determine if one, or a few sites may skew the overall trend of a region or that other outside factors, such as a change in analytical method, change in monitoring frequency, or even a change in sampling technique or personnel do not introduce factors that may artificially alter the true nature of local or regional trends.

Future work will be conducted with this data set including analysis of the effect of additional variables (e.g. climate and deposition, land use, lake area, catchment size, runoff and flow, etc.) which may reveal a more complete picture of the factors driving trends, including diverging and unexpected trends, over time. These additional factors can affect in-stream processes and metal dynamics on both local and broader scales, and likely form a complex group of interacting variables that can drive changes in in-stream chemistry and metal concentrations over short and longer time periods across Sweden.

\section{Summary}

The focus of this study was to determine if trends exist for trace metal concentrations in Swedish streams and rivers and how these trends vary spatially across the country. While some trace metals showed generally consistent relationships across northern and southern regions (As, V, Cr), other metals varied between regions $(\mathrm{Cu}$ and $\mathrm{Pb})$, within regions $(\mathrm{Ni}$ and $\mathrm{Zn}$ ) or showed few trends in either region (Co). The behavior of trace metals can be highly complex due to the variety of biotic and abiotic processes in riverine systems and their respective watersheds. In addition, depositional patterns and climate variability will also exert effects on metals entering and moving within streams and rivers, both directly and indirectly. Although we show some potential in-stream chemistry drivers correlate with trends for some metals, especially TOC and Fe, further exploration and analysis are needed to adequately define the processes that drive changes in metal concentrations in streams across Sweden. Nonetheless, this study shows that concentrations of trace metals in Swedish streams vary temporally and in some cases, spatially. These trends are likely affected by not only general in-stream chemistry, but other, larger scale drivers which are likely to include hydrology, climate variability, and changes in land use. 
Acknowledgements. The authors thank the many people at the laboratory for the Department for Aquatic Sciences and Assessment, SLU who collected and analyzed the substantial amount of samples in this study. Roger Herbert, Louise Björkvald, and Teresia Wällstedt were instrumental in developing a large portion of the database that was used as part of this study. We also thank the Swedish Environmental Protection Agency for funding much of the collection and analysis of the samples and data.

Edited by: T. J. Battin

\section{References}

Adkinson, A., Watmough, S. A., and Dillon, P. J.: Drought-induced metal release from a wetland at Plastic Lake, central Ontario, Can. J. Fish. Aquat. Sci., 65, 834-845, doi:10.1139/F07-195, 2008.

Azimi, S., Rocher, V., Garnaud, S., Varrault, G., and Thevenot, D. R.: Decrease of atmospheric deposition of heavy metals in an urban area from 1994 to 2002 (Paris, France), Chemosphere, 61, 645-651, doi:10.1016/j.chemosphere.2005.03.022, 2005.

Burns, D. A., McHale, M. R., Driscoll, C. T., and Roy, K. M.: Response of surface water chemistry to reduced levels of acid precipitation: comparison of trends in two regions of New York, USA, Hydrol. Process, 20, 1611-1627, doi:10.1002/Hyp.5961, 2006.

Dalva, M. and Moore, T. R.: Sources and sinks of dissolved organiccarbon in a forested swamp catchment, Biogeochemistry, 15, 119, 1991.

Elderfield, H., Upstillgoddard, R., and Sholkovitz, E. R.: The rareearth elements in rivers, estuaries, and coastal seas and their significance to the composition of ocean waters, Geochim. Cosmochim. Ac., 54, 971-991, 1990.

Erlandsson, M., Buffam, I., Folster, J., Laudon, H., Temnerud, J., Weyhenmeyer, G. A., and Bishop, K.: Thirty-five years of synchrony in the organic matter concentrations of Swedish rivers explained by variation in flow and sulphate, Global Change Biol., 14, 1191-1198, doi:10.1111/j.1365-2486.2008.01551.x, 2008.

EUWFD: Directive 2000/60/EC of the European Parliament and of the Council of 23 October 2000 establishing a framework for Community action in the field of water policy, European Parliament, L372, 72, 2000.

Evans, C. D., Monteith, D. T., and Cooper, D. M.: Long-term increases in surface water dissolved organic carbon: observations, possible causes and environmental impacts, Environ. Pollut., 137, 55-71, doi:10.1016/j.envpol.2004.12.031, 2005.

Fitzpatrick, M. L., Long, D. T., and Pijanowski, B. C.: Exploring the effects of urban and agricultural land use on surface water chemistry, across a regional watershed, using multivariate statistics, Appl. Geochem., 22, 1825-1840, doi:10.1016/j.apgeochem.2007.03.047, 2007.

Foster, I. D. L. and Charlesworth, S. M.: Heavy metals in the hydrological cycle: Trends and explanation, Hydrol. Process., 10, 227-261, 1996.

Freeman, C., Evans, C. D., Monteith, D. T., Reynolds, B., and Fenner, N.: Export of organic carbon from peat soils, Nature, 412, 785-785, 2001.
Grybos, M., Davranche, M., Gruau, G., and Petitjean, P.: Is trace metal release in wetland soils controlled by organic matter mobility or Fe-oxyhydroxides reduction?, J. Colloid. Interf. Sci., 314, 490-501, doi:10.1016/j.jcis.2007.04.062, 2007.

Harmens, H., Norris, D. A., Koerber, G. R., Buse, A., Steinnes, E., and Rühling, A.: Temporal trends (1990-2000) in the concentration of cadmium, lead and mercury in mosses across Europe, Environ. Pollut., 151, 368-376, doi:10.1016/j.envpol.2007.06.043, 2008.

Helsel, D. R. and Hirsch, R. M.: Statistical measures in water research, Elsevier Science, Amsterdam, 1992.

Herbert, R.: Background levels of metals in Swedish inland and coastal waters, Report 2009:12, Department of Aquatic Sciences and Assessment, Swedish University of Agricultural Sciences, Uppsala, Sweden, 2009.

Hongve, D., Riise, G., and Kristiansen, J. F.: Increased colour and organic acid concentrations in Norwegian forest lakes and drinking water - a result of increased precipitation?, Aquat. Sci., 66, 231-238, doi:10.1007/s00027-004-0708-7, 2004.

Köhler, S.: Comparing filtered and unfiltered metal concentrations in some swedish surface waters. Report 2010:04, Department of Aquatic Sciences and Assessment, Swedish University of Agricultural Sciences, Uppsala, Sweden, 2010.

Landre, A. L., Watmough, S. A., and Dillon, P. J.: The effects of dissolved organic carbon, acidity and seasonality on metal geochemistry within a forested catchment on the Precambrian Shield, Ontario, Canada, Biogeochemistry, 93, 271-289, 2009.

Lawlor, A. J. and Tipping, E.: Metals in bulk deposition and surface waters at two upland locations in northern England, Environ. Pollut., 121, 153-167, doi:10.1016/s0269-7491(02)00228-2, 2003.

Leenheer, J. A., Brown, G. K., MacCarthy, P., and Cabaniss, S. E.: Models of metal binding structures in fulvic acid from the Suwannee River, Georgia, Environ. Sci. Technol., 32, 24102416, 1998.

Lettenmaier, D. P., Hooper, E. R., Wagoner, C., and Faris, K. B.: Trends in stream quality in the continental United-States, 19781987, Water Resour. Res., 27, 327-339, 1991.

Lindberg, S. E. and Turner, R. R.: Factors influencing atmospheric deposition, stream export, and landscape accumulation of tracemetals in forested watersheds, Water Air Soil Poll., 39, 123-156, 1988.

Loftis, J. C., Taylor, C. H., Newell, A. D., and Chapman, P. L.: Multivariate trend testing of lake water-quality, Water Resour. Bull., 27, 461-473, 1991.

Lofts, S. and Tipping, E.: Solid-solution metal partitioning in the Humber rivers: application of WHAM and SCAMP, Sci. Total Environ., 251, 381-399, 2000.

Martin, J. M., Dai, M. H., and Cauwet, G.: Significance of colloids in the biogeochemical cycling of organic-carbon and tracemetals in the Venice Lagoon (Italy), Limnol. Oceanogr., 40, 119131, 1995.

McBride, M. B.: Environmental chemistry of soils, Oxford University Press, New York, 1994.

McKnight, D. M. and Aitken, G. R.: Sources and age of aquatic humus, Aquatic Humic Substances: Ecology and Biogeochemistry, edited by: Hessen, D. O. and Tranvik, L. J., Springer-Verlag, New York, 1998.

Monteith, D. T., Stoddard, J. L., Evans, C. D., de Wit, H. A., Forsius, M., Hogasen, T., Wilander, A., Skjelkvale, B. L., Jef- 
fries, D. S., Vuorenmaa, J., Keller, B., Kopacek, J., and Vesely, J.: Dissolved organic carbon trends resulting from changes in atmospheric deposition chemistry, Nature, 450, 537-U539, doi:10.1038/Nature06316, 2007.

Olivie-Lauquet, G., Gruau, G., Dia, A., Riou, C., Jaffrezic, A., and Henin, O.: Release of trace elements in wetlands: role of seasonal variability, Water Res., 35, 943-952, doi:10.1016/s00431354(00)00328-6, 2001.

Pokrovsky, O. S. and Schott, J.: Iron colloids/organic matter associated transport of major and trace elements in small boreal rivers and their estuaries (NW Russia), Chem. Geol., 190, 141-179, doi:10.1016/s0009-2541(02)00115-8, 2002.

Pokrovsky, O. S., Viers, J., Shirokova, L. S., Shevchenko, V. P., Filipov, A. S., and Dupré, B.: dissolved, suspended, and colloidal fluxes of organic carbon, major and trace elements in the Severnaya Dvina River and its tributary, Chem. Geol., 273, 136-149, doi:10.1016/j.chemgeo.2010.02.018, 2010.

Porcal, P., Koprivnjak, J. F., Molot, L. A., and Dillon, P. J.: Humic substances-part 7: the biogeochemistry of dissolved organic carbon and its interactions with climate change, Environ. Sci. Pollut. R., 16, 714-726, doi:10.1007/s11356-009-0176-7, 2009.

Ross, J. M. and Sherrell, R. M.: The role of colloids in tracemetal transport and adsorption behavior in New Jersey pinelands streams, Limnol. Oceanogr., 44, 1019-1034, 1999.

Rühling, A. and Tyler, G.: Regional differences in deposition of heavy metals over Scandinavia, J. Appl. Ecol., 8, 497-507, 1971.

Rühling, A. and Tyler, G.: Changes in atmospheric deposition rates of heavy metals in Sweden a summary of nationwide Swedish surveys in 1968/70 - 1995, Water, Air Soil Poll.: Focus, 1, 311323, doi:10.1023/a:1017584928458, 2001.

Rühling, A. and Tyler, G.: Changes in the atmospheric deposition of minor and rare elements between 1975 and 2000 in south Sweden, as measured by moss analysis, Environ. Pollut., 131, 417423, doi:10.1016/j.envpol.2004.03.005, 2004.

Salomons, W. and Eysink, W.: Pathways of mud and particulate trace metals from rivers to the South North Sea, Special Publication of the International Association of Sedimentologists, 5, 429-450, 1979.

Salomons, W. and Forstner, U.: Metals in the hydrolcycle, SpringerVerlag, Berlin, 1984

Sauve, S., McBride, M. B., Norvell, W. A., and Hendershot, W. H.: Copper solubility and speciation of in situ contaminated soils: Effects of copper level, $\mathrm{pH}$ and organic matter, Water Air Soil Poll., 100, 133-149, 1997.
Schut, P. H., Evans, R. D., and Scheider, W. A.: Variation in tracemetal exports from small Canadian Shield watersheds, Water Air Soil Poll., 28, 225-237, 1986.

Sherrell, R. M. and Ross, J. M.: Temporal variability of trace metals in New Jersey Pinelands streams: Relationships to discharge and pH, Geochim. Cosmochim. Ac., 63, 3321-3336, 1999.

Sholkovitz, E. R.: Flocculation of dissolved organic and inorganic matter during mixing of river water and seawater, Geochim. Cosmochim. Ac., 40, 831-845, 1976.

Skjelkvale, B. L., Stoddard, J. L., Jeffries, D. S., Torseth, K., Hogasen, T., Bowman, J., Mannio, J., Monteith, D. T., Mosello, R., Rogora, M., Rzychon, D., Vesely, J., Wieting, J., Wilander, A., and Worsztynowicz, A.: Regional scale evidence for improvements in surface water chemistry 1990-2001, Environ. Pollut., 137, 165-176, doi:10.1016/j.envpol.2004.12.023, 2005.

Statens offentliga utredningar (SOU): Sweden before climate change - threats and possibilities, 2007:60, Stockholm, Sweden, 2007.

Thurman, E. M.: Organic Geochemistry of Natural Waters, Kluwer Academic Publishers Group, Dordrecht, Germany, 1985.

Tipping, E., Rothwell, J. J., Shotbolt, L., and Lawlor, A. J.: Dynamic modelling of atmospherically-deposited $\mathrm{Ni}, \mathrm{Cu}, \mathrm{Zn}, \mathrm{Cd}$ and $\mathrm{Pb}$ in Pennine catchments (northern England), Environ. Pollut., 158, 1521-1529, doi:10.1016/j.envpol.2009.12.026, 2010.

Wällstedt, T., Björkvald, L., and Gustafsson, J. P.: Increasing concentrations of arsenic and vanadium in (southern) Swedish streams, Appl. Geochem., 25, 1162-1175, doi:10.1016/j.apgeochem.2010.05.002, 2010.

Warnken, K. W., Lawlor, A. J., Lofts, S., Tipping, E., Davison, W., and Zhang, H.: In situ speciation measurements of trace metals in headwater streams, Environ. Sci. Technol., 43, 7230-7236, doi:10.1021/es900112w, 2009.

Wen, L. S., Santschi, P. H., and Tang, D. G.: Interactions between radioactively labeled colloids and natural particles: Evidence for colloidal pumping, Geochim. Cosmochim. Ac., 61, 2867-2878, 1997.

Worrall, F. and Burt, T.: Time series analysis of long-term river dissolved organic carbon records, Hydrol. Process., 18, 893-911, doi:10.1002/Hyp.1321, 2004.

Worrall, F., Harriman, R., Evans, C. D., Watts, C. D., Adamson, J., Neal, C., Tipping, E., Burt, T., Grieve, I., Monteith, D., Naden, P. S., Nisbet, T., Reynolds, B., and Stevens, P.: Trends in dissolved organic carbon in UK rivers and lakes, Biogeochemistry, 70, 369-402, 2004. 